\title{
PERENCANAAN PERSEDIAAN KOMPONEN PADA PERUSAHAAN ORIGINAL EQUIPMENT MANUFACTURER MENGGUNAKAN METODE PERSEDIAAN DETERMINISTIK DINAMIS
}

\author{
${ }^{1}$ Erika Fatma, ${ }^{2}$ Intan Indriani R, ${ }^{3}$ Messy Fitriana \\ 1,2,3Program Studi Manajemen Logistik Industri Elektronika, Politeknik APP Jakarta \\ Jl. Timbul no. 34 Ciganjur, Jagakarsa, Jakarta Selatan \\ e-mail: rika-fatma@kemenperin.go.id
}

\begin{abstract}
Determination of inventory of raw materials and components is needed to support the smoothness of the production process. Inventory management is done, in order to determine optimum inventory level, order lot size and reorder time that can minimize total inventory cost. This research applies some method in dynamic deterministic inventory model by comparing those method based on the lowest inventory total cost. This model solved basic inventory management problems, which are the number of goods to be ordered for each time the order made, when the order needs to be made (r) and safety stock level. Based on this research, it is known that the company may decrease its inventory cost by implementing suggested inventory method.
\end{abstract}

Key words : Inventory control; dynamic deterministic; optimal inventory; reorder point

\section{PENDAHULUAN}

Persediaan merupakan cadangan yang dibutuhkan perusahaan untuk menjamin kelancaran proses bisnisnya. Bagi perusahaan manufaktur dan assembling, ketersediaan bahan baku dan komponen merupakan elemen penting untuk memastikan proses produksi dilakukan sesuai target, baik kuantitas, kualitas maupun jadwal yang telah ditetapkan (Chang, 2016). Persediaan bahan baku/ komponen yang disiapkan oleh perusahaan, sangat terkait dengan tingkat permintaan produk jadi yang dihasilkan. Ketidaktepatan dalam pengelolaan persediaan menyebabkan perusahaan tidak dapat beroperasi secara optimal atau tidak mendapatkan keuntungan maksimal.

Perusahaan yang diamati merupakan produsen komponen elektronika (Original Equipment Manufacturer/OEM), yaitu perusahaan yang memproduksi komponen/alat sesuai kebutuhan dan spesifikasi perusahaan lain (Wonglimpiyarat, 2018). Dalam menjalankan proses manufakturnya, perusahaan berpatokan pada kebutuhan spesifik dari tiap perusahaan yang menjadi pelanggannya. Seluruh produk yang dihasilkan, dibuat dirancang, direkayasa dan dibangun sesuai spesifikasi khusus yang ditentukan pelanggan. Saat ini, perusahaan menawarkan pelayanan terpadu dimulai dari proses inspeksi, penyimpanan, perakitan dan pemasangan komponen, pengecekan dan pengendalian kualitas produk melalui proses Factory Acceptance Test, hingga tahapan pengemasan dan pengiriman. Keseluruhan proses tersebut dilakukan untuk memastikan kepuasan pelanggan dan menjamin bahwa produk yang dihasilkan sudah sesuai dengan kebutuhan konsumen.

Perusahaan beroperasi secara Make to Order untuk memenuhi kebutuhan konsumennya. Perusahaan memiliki kontrak produksi alat elektronik industri dengan perusahaan pelanggan untuk jangka waktu panjang. Saat ini perusahaan mendasarkan jumlah pemesanan bahan baku berdasarkan jumlah permintaan pada setiap periode yang ditetapkan oleh pelanggan. Sayangnya, perhitungan ukuran pemesanan optimal dalam pemesanan bahan baku belum dilakukan secara menyeluruh. Selama ini perusahaan berpatokan pada jumlah kebutuhan spesifik konsumen tiap periodenya. Permasalahan lain, waktu kedatangan bahan baku tidak tetap, hal ini menyebabkan perusahaan harus menyediakan cadangan pengaman yang cukup tinggi, untuk mengantisipasi terjadi keterlambatan kedatangan barang dari supplier. Saat ini perusahaan belum menerapan metode perhitungan ilmiah tertentu dalam pengelolan persediaan, khususunya dalam penentuan ukuran pemesanan, kapan melakukan pemesanan kembali dan cadangan pengaman.

Penentuan pemesanan bahan baku yang tidak tepat akan menimbulkan biaya pemesanan dan biaya simpan yang besar karena tidak optimalnya ukuran pemesanan (Maulana \& 
Kusumawardhani, 2015). Sehingga, perlu dilakukan pengendalian persediaaan yang tepat untuk mengetahui tingkat persediaan optimum agar biaya total persediaan yang dikeluarkan dapat ditekan menjadi lebih rendah. Manajemen persediaan merupakan rangkaian kegiatan menentukan tingkat dan komposisi persediaan yang tepat untuk menyeimbangkan tingkat kepuasan pelanggan dan biaya yang dikeluarkan (Siagian, 2007). Persediaan merupakan investasi yang tertanam pada perusahaan, investasi yang terlalu besar dapat menimbulkan resiko, seperti kerusakan, keusangan dan penurunan nilai pada persediaan, sebaliknya investasi yang terlalu rendah dapat menimbulkan resiko produksi terhambat yang dapat menimbulkan kekecewaan konsumen (Taryana, 2008). Kegiatan pengendalian yang tepat membantu perusahaan untuk menjaga kelancaran produksi dan pemenuhan kebutuhan produksi dengan tetap memperhatikan biaya persediaan minimum.

Sebagai perusahaan kontrak (OEM), perusahaan terikat permintaan dalam jumlah tertentu yang ditentukan oleh konsumen dalam jangka waktu tertentu. Jumlah permintaan berfluktuasi namun jumlahnya telah ditetapkan oleh konsumennya untuk beberapa periode kedepan. Dalam kasus seperti ini model pengendalian persediaan deterministik dinamis dapat digunakan. Model persediaan deterministik dinamis merupakan model yang digunakan jika permintaan barang diketahui secara pasti namun besarnya permintaan bervariasi antara satu periode dengan periode lainnya (Tersine, 1994). Model persediaan deterministik dinamis terdiri dari berbagai metode yang bertujuan untuk menentukan ukuran atau waktu pemesanan dengan mempertimbangkan biaya pesan dan biaya simpan (Bushuev, Guiffrida, \& Jaber, 2015). Metode terbaik yang digunakan adalah metode yang dapat memberikan nilai total biaya persediaan terendah (Nur Bahagia, 2006).

Berdasarkan perumusan sebelumnya dan permasalahan yang ditemui di perusahaan, maka penelitian ini bertejuan untuk mengetahui kebijakan pengendalian persediaan perusahaan, yang meliputi, tingkat persediaan optimum, ukuran dan jadwal pemesanan kembali, serta persediaan pengaman yang perlu dipersiapkan perusahaan untuk mengantisipasi ketidakpastian waktu pengiriman. Penelitian ini dibatasi pada salah satu jenis persediaan yaitu komponen yaitu door hook yang digunakan untuk memproduksi salah satu produk yang diproduksi.

\section{METODE PENELITIAN}

\section{A. Pengolahan Data}

Pengumpulan data dilakukan melalui observasi langsung, analisa dokumen perusahaan, dan wawancara dengan manajemen perusahaan. Data yang dikumpulkan antara lain data permintaan produk, komponen biaya penyusun biaya persediaan, yaitu biaya pembelian, biaya pesan, biaya penyimpanan dan biaya terkait lainnya. Selain itu, untuk mendukung penentuan persediaan optimum, data lain yang dikumpulkan adalah informasi mengenai lead time pemesanan, sistem kerja perusahaan (SOP) terkait pengelolaan persediaan dan karakteristik permitaan.

\section{B. Persediaan Optimum}

Kebijakan persediaan optimal dilakukan berdasarkan perbandingan beberapa metode persediaan deterministk dinamis. Kebijakan persediaan optimum dilakukan dengan menghitung jumlah ukuran pemesanan (lot size), titik pemesanan kembali (reorder point) dan total biaya persediaan setiap metode diantaranya biaya pesan, simpan, dan harga satuan, dan data lead time. Menurut (Nur Bahagia, 2006) penjelasan dari setiap metode adalah sebagai berikut:

\section{Lot For Lot (LFL)}

Metode LFL berdasarkan pada konsep untuk menyediakan persediaan sesuai kebutuhan pada periode tersebut (Tiwari, dkk., 2018). Metode LFL tidak menggunakan persediaan, sehingga tidak menimbulkan biaya simpan. Namun, dalam kondisi biaya persediaan yang tinggi, metode ini tidak optimal karena dapat menimbulkan biaya pemesanan yang tinggi. 


\section{Period Order Quantity (POQ)}

Metode POQ didasarkan pada asumsi bahwa ukuran pemesanan (lot) optimum dapat berubah untuk tiap pemesanan, namun dengan rentang waktu/periode pemesanan tetap (Simatupang, 2017). Metode POQ menggunakan konsep dasar yang sama dengan metode EOQ. Metode EOQ didasarkan pada asumsi bahwa ukuran pemesanan optimum terjadi ketika biaya total pemesanan sama dengan total biaya simpan dalam suatu rentang periode. Ukuran pemesanan dalam metode EOQ, dirumuskan pada Persamaan 1.

$$
\mathrm{EOQ}=\sqrt{\frac{2 . S \cdot D}{H}}
$$

$$
\begin{aligned}
& \text { dimana }: E O Q=\text { jumlah pembelian ekonomis } \\
& \mathrm{S} \text { = biaya setiap kali pemesanan } \\
& \mathrm{D}=\text { kebutuhan bahan baku } 1 \text { periode } \\
& \mathrm{H} \text { = biaya penyimpanan }
\end{aligned}
$$

Namun demikian, metode POQ lebih ditujukan untuk memenuhi kebutuhan produksi. Asumsi yang digunakan dalam sistem ini adalah periode/waktu antara pesanan (T) konstan, dan kuantitas untuk setiap pesanan dapat bervariasi.

\section{Least Unit Cost (LUC)}

Metode LUC menggunakan konsep untuk memilih biaya per unit terkecil selama periode berurutan (Miguella-Canela, 2018). Metode ini menggunakan jarak permintaan yang akan datang menggunakan tabel perencanaan kebutuhan material (MRP) untuk melengkapi kuantitas permintaan aktual dan usaha untuk meminimasi biaya total persediaan. Perhitungan dilakukan menggunakan iterasi untuk menghitung ongkos persediaan per unit yang mencakup beberapa periode permintaan, jika biaya perunit gabungan dari beberapa periode nilainya menurun, maka gabungkan nilai permintaan periode berikutnya. Namun jika nilainya membesar, maka hentikan perhitungan, dan mulai kembali perhiungan untuk periode berikutnya.

\section{Equivalent Part Period (EPP)}

Metode PPB, merupakan variasi metode LUC, dengan prinsip perhitungan seperti LUC yang berusaha untuk menyeimbangkan biaya pemesanan dengan biaya simpan berdasarkan pendekatan konsep Equivalent Part Period (EPP) (Chandradevi \& Puspitasari, 2016). Perhitungan EPP dilakukan menggunakan persamaan 2.

$$
\mathrm{EPP}=\frac{s}{k}
$$

dengan: $\quad s=$ biaya pesan

$$
\mathrm{k}=\text { biaya simpan }
$$

\section{Silver Meal Algorithm (SMA)}

Metode ini memiliki konsep seperti LUC, namun metode ini memilih ongkos persediaan terkecil selama cakupan periode berurutan dengan menggabungkan kebutuhan beberapa periode sampai biaya penyimpanan mendekati biaya pemesanan (Tersine, 1994). Metode SMA dirumuskan seperti pada Persamaan 3.

$$
\text { Total ongkos/periode }=\frac{\text { ongkos_pesan }+ \text { ongkos_simpan_kumulatif }}{J m l_{-} \text {periode_kumulatif }}
$$




\section{Wagner Within Algorithm (WWA)}

Metode WWA merupakan variasi model deterministik dinamis. Metode ini diharapkan dapat memberikan total biaya persediaan minimum, karena metode ini menggunakan pendekatan dinamis dan matematisnya yang detail. Perhitungan ongkos pesan dan simpan, dilakukan menggunakan matrik untuk semua alternative pesanan pada horizon waktu $\mathrm{N}$ perioda $\left(\mathrm{Z}^{\mathrm{ce}}\right)$. Perjitungan metode WWA, ditampilkan pada Persamaan 4.

$$
\mathrm{Z}^{\mathrm{ce}}=\mathrm{C}+P i \sum_{k=c}^{e}(\stackrel{c e}{Q}-\stackrel{c i}{Q}), \text { untuk } 1 \leq \mathrm{c} \leq \mathrm{e} \leq \mathrm{N}
$$

$$
\begin{aligned}
\text { Dengan }: \mathrm{C} & =\text { Biaya Pesan } \\
\mathrm{Pi} & =\text { Biaya Simpan }
\end{aligned}
$$

Menentukan Biaya Minimum

$f_{e}=\operatorname{Min} .\left(Z_{c e}+f_{c-1}\right)$, untuk $C=1,2$,

\section{Biaya Total Persediaan}

Solusi pengendalian persediaan terbaik dipilih berdasarkan beberapa alternatif dari solusi yang tersedia. Kerena perusahaan yang dipilih adalah perusahaan contract manufaktur, yang memenuhi jumlah permintaan yang pasti, maka tingkat layanan pelanggan sudah pasti. Maka untuk mencari alternatif solusi terbaik mana yang akan dipilih digunakan criteria minimasi ongkos inventori total selama horizon perencanaan (misalnya satu tahun) (Russell \& Taylor, 2008). Komponen biaya dihitung menggunakan beberapa berdasarkan persamaan 5 .

$$
\mathrm{OT}=\mathrm{Op}+\mathrm{Os}
$$

$$
\begin{aligned}
& \text { Dimana: OT : Ongkos inventori total per tahun } \\
& \text { Op : Ongkos pesan per tahun } \\
& \text { Os : Ongkos simpan per tahun }
\end{aligned}
$$

\section{Persediaan Pengaman dan Titik Pemesanan Kembali}

Persediaan pengaman merupakan persediaan yang disiapkan untuk menanggulangi jika terjadi permintaan atau pemakaian bahan baku yang tidak diduga karena adanya ketidakpastian tingkat permintaan dan fluktuasi waktu tunggu (Herjanto, 2007). Persediaan pengaman didefinisikan sebagai persediaan yang dicadangkan sebagai pengaman kelangsungan produksi perusahaan. Dengan persediaan pengaman diharapkan proses produksi tidak terganggu oleh ketidakpastian permintaan atau kedatangan bahan baku dari supplier. Sedangkan titik pemesanan kembali, merupakan titik di mana harus dilakukan pesanan dengan mempertimbangkan lead time, agar kedatangan material tepat pada waktu dimana persediaan di atas safety stock sama dengan nol (Rahmayanti \& Fauzan, 2013). Perhitungan persediaan pengaman dan titik pemesanan kembali, dilakukan menggunakan berdasarkan (Tersine, 1994) dengan waktu kedatangan yang tidak seragam, sesuai persamaan 6.

$$
\text { Persediaan Pengaman }=Z_{\propto} \sqrt{\bar{L} S^{2}+D^{2} \cdot S_{L}^{2}}
$$

Dimana: $\mathrm{L}$ : rata-rata lead time

$\mathrm{S}$ : standar deviasi permintaan selama lead time

$\mathrm{S}_{\mathrm{L}}:$ standar deviasi lead time 


\section{HASIL DAN PEMBAHASAN}

\section{A. Pengolahan Data Persediaan}

Pengolahan data persediaan dilakukan dengan menghitung biaya yang timbul dengan model deterministik dinamis, dengan mempertimbangkan biaya pesan dan biaya simpan. Setelah mengetahui komponen harga penyusun ongkos total. Maka dapat membuat rencana kebutuhan material untuk mengetahui ongkos total yang timbul. Membandingkan beberapa metode untuk menentukan kebijakan inventory yang optimal dari metode deterministik statis.

Data yang diperoleh dari perusahaan adalah data-data yang diperlukan untuk menentukan kebijakan persediaan, yaitu: data permintaan produk switchboard periode Januari - Desember 2016. Data permintaan tersebut dapat dilihat dalam Tabel 4.1. Dalam model deterministik dinamis terdapat beberapa penyelesaian inventori dinamis yang digunakan, yaitu dengan metode Lot For Lot, Periodic Order Quantity, Least Unit Cost, Equivalent Part Period, Algoritma Silver Meal, dan Algoritma Wagner Within.

Berdasarkan data permintaan produk switchboard tersebut, nantinya akan diturunkan ke level 1 dan level 2 untuk menentukan kebijakan persediaan produk Door hook. Untuk menyusun 1 unit produk jadi dibutuhkan 1 unit front panel protection window, dan untuk menyusun 1 front panel protection window dibutuhkan 8 unit door hook. Selain data permintaan, diperlukan data mengenai biaya untuk menghitung total biaya persediaan yang dikeluarkan oleh perusahaan. Data biaya yang dibutuhkan adalah biaya pesan untuk setiap satu kali pemesanan dan data biaya simpan untuk setiap material dalam suatu periode. Biaya pemesanan/pesan merupakan biaya yang dikeluarkan untuk setiap kali melakukan pemesanan kepada pemasok,sedangkan biaya penyimpanan merupakan biaya yang dikeluarkan untuk menyimpan/menjaga suatu produk di gudang. Informasi mengenai biaya pemesanan dan biaya simpan diperoleh berdasarkan hasil observasi dan wawancara dengan pihak perusahaan, dan hasil perhitungan. Besaran biaya pesan dan biaya simpan, disajikan dalam Tabel 1, sedangkan Tabel 2 menyajikan data permintaan produk switchboard tahun 2017.

Tabel 1. Biaya pesan dan biaya simpan

\begin{tabular}{lllr}
\hline Jenis Biaya & & Raw Material \\
\hline Biaya Pemesanan/ Pesan & Bongkar muat & Rp. & 200.000 \\
& Biaya angkut & Rp. & 1.750 .000 \\
& Biaya administrasi & Rp. & 150.000 \\
& Total & Rp. & 2.100 .000 \\
Biaya Simpan /Unit/bulan & Biaya perawatan & Rp. & 250 \\
& Penyusutan nilai & Rp. & 350 \\
& Total & Rp. & 600 \\
\hline
\end{tabular}

Tabel 2. Data permintaan produk switchboard tahun 2017

\begin{tabular}{llllll}
\hline Periode & $\begin{array}{l}\text { Permintaan } \\
\text { Doorhook }\end{array}$ & Lead time & Periode & $\begin{array}{l}\text { Permintaan } \\
\text { Doorhook }\end{array}$ & Lead time \\
\hline Januari 2017 & 3136 & 5 minggu & Juli 2017 & 3460 & 5 minggu \\
Februari 2017 & 3320 & 4 minggu & Agustus 2017 & 2016 & 4 minggu \\
Maret 2017 & 3100 & 4 minggu & September 2017 & 5416 & 3 minggu \\
April 2017 & 2688 & 3 minggu & Oktober 2017 & 5212 & 3 minggu \\
Mei 2017 & 2280 & 3 minggu & November 2017 & 4920 & 5 minggu \\
Juni 2017 & 4164 & 5 minggu & Desember 2017 & 5320 & 6 minggu \\
\hline
\end{tabular}

\section{B. Perhitungan Nilai Persediaaan Optimum}

Perhitungan persediaan optimum produk door hook, dilakukan dengan menentukan ukuran lot pemesanan yang memberikan biaya minimum. Biaya yang dipertimbangkan dibatasi hanya biaya pemesanan dan biaya simpan. Biaya pembelian dianggap konstan. 


\section{Lot For Lot (LFL)}

Dalam metode LFL, pemesanan dilakukan setiap periode sesuai dengan kebutuhan setiap periode. Dalam metode LFL, perusahaan tidak memiliki persediaan. Rencana pembelian dan biaya persediaan metode LFL ditampilkan pada Tabel 3.

Tabel 3. Rencana pembelian dan biaya persediaan metode LFL

\begin{tabular}{lllllllllllll}
\hline & $\mathbf{1}$ & $\mathbf{2}$ & $\mathbf{3}$ & $\mathbf{4}$ & $\mathbf{5}$ & $\mathbf{6}$ & $\mathbf{7}$ & $\mathbf{8}$ & $\mathbf{9}$ & $\mathbf{1 0}$ & $\mathbf{1 1}$ & $\mathbf{1 2}$ \\
\hline $\mathbf{D}$ & 3.136 & 3.320 & 3.100 & 2.688 & 2.280 & 4.164 & 3.460 & 2.016 & 5.416 & 5.212 & 4.920 & 5.320 \\
$\mathbf{Q}$ & 3.136 & 3.320 & 3.100 & 2.688 & 2.280 & 4.164 & 3.460 & 2.016 & 5.416 & 5.212 & 4.920 & 5.320 \\
\hline
\end{tabular}

$$
\begin{aligned}
& \text { Biaya Simpan }=\text { Biaya Pesan } \quad+\text { Biaya Simpan } \\
& =12 * \text { Rp. } 2 \cdot 100.000+\text { Rp. } 0=\text { Rp. } 24 \cdot 900 \cdot 000,00
\end{aligned}
$$

\section{Period Order Quantity (POQ)}

Berdasarkan persamaan (1), diketahui bahwa ukuran pemesanan ekonomis adalah:

$$
\operatorname{EOQ}(q *)=\sqrt{\frac{2 . S . D}{H}}=\sqrt{\frac{2 * 2.100 .000 * 45.032}{600}}=17.755 \text { unit }
$$

Berdasarkan hasil EOQ, diketahui pemesanan dilakukan sebanyak 4 kali (Permintaan total dibagi EOQ). Metode POQ membagi jumlah total horizon perencanaan (12 bulan) dengan frekuensi pemesanan (4 kali) sehingga diketahui pemesanan dilakukan setiap 3 bulan sekali. Sehingga diperoleh rencana dan biaya pemesanan metode POQ pada Tabel 4

Tabel 4. Rencana pembelian dan biaya persediaan metode POQ

\begin{tabular}{lllllllrllrll}
\hline & $\mathbf{1}$ & $\mathbf{2}$ & $\mathbf{3}$ & $\mathbf{4}$ & $\mathbf{5}$ & $\mathbf{6}$ & $\mathbf{7}$ & $\mathbf{8}$ & $\mathbf{9}$ & $\mathbf{1 0}$ & $\mathbf{1 1}$ & $\mathbf{1 2}$ \\
\hline D & 3.136 & 3.320 & 3.100 & 2.688 & 2.280 & 4.164 & 3.460 & 2.016 & 5.416 & 5.212 & 4.920 & 5.320 \\
Q & 9.556 & & & 9.132 & & & 10.892 & & & 15.452 & &
\end{tabular}

$$
\begin{aligned}
\text { Biaya Simpan } & =\text { Biaya Pesan } \\
& =4 * \text { Rp. } 2.100 .000+\text { Biaya Simpan } \\
& +43.880 \text { unit } * \text { Rp. } 600=\text { Rp. } 34.728 .000
\end{aligned}
$$

\section{Least Unit Cost (LUC)}

Metode LUC dilakukan dengan memilih periode pesanan dengan cakupan pemesanan yang dapat memberikan biaya per unit terkecil selama periode berurutan. Rencana dan biaya persediaan LUC pada Tabel 5.

Tabel 5. Rencana pembelian dan biaya persediaan metode LUC

\begin{tabular}{lllllllllllll}
\hline & $\mathbf{1}$ & $\mathbf{2}$ & $\mathbf{3}$ & $\mathbf{4}$ & $\mathbf{5}$ & $\mathbf{6}$ & $\mathbf{7}$ & $\mathbf{8}$ & $\mathbf{9}$ & $\mathbf{1 0}$ & $\mathbf{1 1}$ & $\mathbf{1 2}$ \\
\hline D & 3.136 & 3.320 & 3.100 & 2.688 & 2.280 & 4.164 & 3.460 & 2.016 & 5.416 & 5.212 & 4.920 & 5.320 \\
$\mathbf{Q}$ & 6.456 & & 5.788 & & 6.444 & & 5.476 & & 5.416 & 5.212 & 4.920 & 5.320 \\
\hline
\end{tabular}

$$
\begin{aligned}
\text { Biaya Simpan } & =\text { Biaya Pesan } \\
& =8 * \text { Rp. } 2.100 .000+\text { Biaya Simpan } \\
& +12.188 \text { unit } * \text { Rp. } 600=\text { Rp. } 24.112 .800
\end{aligned}
$$

\section{Equivalent Part Period (EPP)}

Metode EPP dilakukan dengan menyeimbangkan antara biaya pemesanan dan biaya simpan. Berdasarkan persamaan 4, diketahui bahwa nilai EPP sebesar Rp. 3.500 unit, sehingga dapat dithitung periode pemesanan dan biaya metode EPP pada Tabel 6 
Tabel 6. Rencana pembelian dan biaya persediaan metode EPP

\begin{tabular}{lllllllllllll}
\hline & $\mathbf{1}$ & $\mathbf{2}$ & $\mathbf{3}$ & $\mathbf{4}$ & $\mathbf{5}$ & $\mathbf{6}$ & $\mathbf{7}$ & $\mathbf{8}$ & $\mathbf{9}$ & $\mathbf{1 0}$ & $\mathbf{1 1}$ & $\mathbf{1 2}$ \\
\hline $\mathbf{D}$ & 3.136 & 3.320 & 3.100 & 2.688 & 2.280 & 4.164 & 3.460 & 2.016 & 5.416 & 5.212 & 4.920 & 5.320 \\
$\mathbf{Q}$ & 3.136 & 3.320 & 3.100 & 2.688 & 2.280 & 4.164 & 3.460 & 2.016 & 5.416 & 5.212 & 4.920 & 5.320 \\
\hline
\end{tabular}

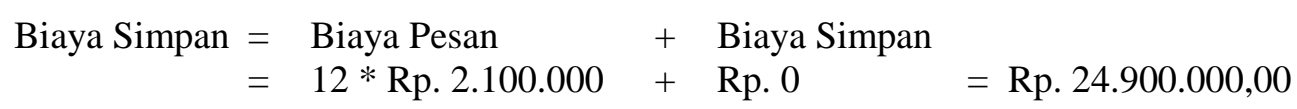

\section{Silver Meal Algorithm (SMA)}

Metode SMA dilakukan dengan memilih biaya terkecil dengan menggabungkan beberapa periode berurutan kebutuhan beberapa periode sampai biaya penyimpanan mendekati biaya pemesanan. Perencanaan persedian dan biaya persediaan SMA ditampilkan pada Tabel 7

Tabel 7. Rencana pembelian dan biaya persediaan metode SMA

\begin{tabular}{|c|c|c|c|c|c|c|c|c|c|c|c|c|}
\hline & 1 & 2 & 3 & 4 & 5 & 6 & 7 & 8 & 9 & 10 & 11 & 12 \\
\hline D & 3.136 & 3.320 & 3.100 & 2.688 & 2.280 & 4.164 & 3.460 & 2.016 & 5.416 & 5.212 & 4.920 & 5.320 \\
\hline $\mathbf{Q}$ & 6.456 & & 5.788 & & 6.444 & & 5.476 & & 5.416 & 5.212 & 4.920 & 5.320 \\
\hline
\end{tabular}

$$
\begin{aligned}
\text { Biaya Simpan } & =\text { Biaya Pesan } \\
& =8 * \text { Rp. } 2.100 .000+\text { Biaya Simpan } \\
& +12.188 \text { unit } * \text { Rp. } 600=\text { Rp. } 24.112 .800
\end{aligned}
$$

\section{Wagner Within Algorithm (WWA)}

Metode WWA dilakukan dengan mencari total biaya minimum menggunakan program dinamis dan pendekatan matematis yang detail sehingga diperoleh biaya minimum. Perencanaan persedian dan biaya persediaan WWA ditampilkan pada Tabel 8

Tabel 8. Rencana pembelian dan biaya persediaan metode WWA

\begin{tabular}{lllllllllllll}
\hline & $\mathbf{1}$ & $\mathbf{2}$ & $\mathbf{3}$ & $\mathbf{4}$ & $\mathbf{5}$ & $\mathbf{6}$ & $\mathbf{7}$ & $\mathbf{8}$ & $\mathbf{9}$ & $\mathbf{1 0}$ & $\mathbf{1 1}$ & $\mathbf{1 2}$ \\
\hline $\mathbf{D}$ & 3.136 & 3.320 & 3.100 & 2.688 & 2.280 & 4.164 & 3.460 & 2.016 & 5.416 & 5.212 & 4.920 & 5.320 \\
$\mathbf{Q}$ & 6.456 & & 5.788 & & 6.444 & & 5.476 & & 5.416 & 5.212 & 4.920 & 5.320 \\
\hline
\end{tabular}

$$
\begin{aligned}
\text { Biaya Simpan } & =\text { Biaya Pesan } \\
& =8 * \text { Rp. } 2.100 .000+\text { Biaya Simpan } \\
& +12.188 \text { unit } * \text { Rp. } 600=\text { Rp. } 24.112 .800
\end{aligned}
$$

\section{Persediaan Pengaman dan Titik Pemesanan Kembali}

Perusahaan menetapkan bahwa sejumlah persediaan pengaman harus disediakan untuk mengantisipasi ketidakpastian kedatangan bahan baku. Saat ini perusahaan menetapkan jumlah persediaan pengaman sebesar $20 \%$ dari rata-rata jumlah permintaan, atau sejumlah 751 unit. Berdasarkan persamaan (7), dengan nilai $\alpha$ sebesar 2.65, diperoleh nilai persediaan pengaman sebesar 208 unit. Nilai persediaan ini lebih rendah dibandingkan dengan kebijakan yang selama ini digunakan oleh perusahaan. Dengan menurunkan safety stock, permintaan tetap dapat terpenuhi dengan biaya persediaan yang lebih rendah.

\section{SIMPULAN}

Metode pengelolaan inventori optimum yang dipilih adalah metode LUC, SMA, dan WMA karena memberikan biaya total persediaan yang paling rendah, sebesar Rp. 24.112.800. Nilai persediaan tersebut lebih rendah, dibandingkan biaya yang dikeluarkan oleh perusahaan dengan menggunakan metode LFL. Persediaan pengaman dapat diturunkan menjadi sepertiga persediaanawal, yaitu dari 751 unit, menjadi 208 unit. Penurunan ini dapat menurunkan biaya simpan untuk persediaan pengaman dengan tetap memastikan produk tersedia untuk proses produksi . 
Beberapa pengembangan dapat dilakukan untuk mengembangkan hasil penelitian ini, Asumsi mengenai harga pembelian konstan, dapat dikembangkan dengan penambahan faktor quantity discount, sehingga harga pembelian dapat berbeda jika perusahaan membeli produk dalam jumlah besar. Selain itu, faktor kapasitas penyimpanan gudang, juga dapat ditambahkan untuk memberikan batasan jumlah pembelian yang dilakukan perusahaan.

\section{DAFTAR PUSTAKA}

Bushuev, M. A., Guiffrida, A., Jaber, M. Y., \& Khan, M. (2015). A review of inventory lot sizing review papers. Management Research Review, 38(3), 283-298.

Chandradevi, A., \& Puspitasari, N. B. (2016). Penerapan Material Requirement Planning (MRP) dengan Mempertimbangkan Lot Sizing dalam Pengendalian Bahan Baku pada PT. Phapros, Tbk. PERFORMA: Media Ilmiah Teknik Industri, 15(1).

Chang, C. T. (2016). Inventory models with stock-and pricedependent demand for deteriorating items based on limited shelf space. Yugoslav Journal of Operations Research, 20(1).

Herjanto, E. (2007). Manajemen Operasi (Edisi 3). Grasindo: Jakarta.

Maulana, A., \& Kusumawardhani, A. (2015). Analisis Efisiensi Persediaan Bahan Baku Susu Sapi Murni Dengan Menggunakan Metode Economic Order Quantity Pada Soto Sedeep. Semarang: Universitas Diponegoro (Doctoral dissertation, Fakultas Ekonomika dan Bisnis).

Nur Bahagia, S. (2006). Sistem Inventory. Bandung: ITB Publisher.

Minguella-Canela, J., Morales Planas, S., Gomà Ayats, J., \& de los Santos López, M. (2018). Assessment of the potential economic impact of the use of AM technologies in the cost levels of manufacturing and stocking of spare part products. Materials, 11(8), 1429.

Rahmayanti, D., \& Fauzan, A. ( 2013). Optimalisasi sistem persediaan bahan baku karet mentah (lateks) dengan metode Lot Sizing (studi kasus: PT Abaisiat Raya). Jurnal Optimasi Sistem Industri, 12(1), 317-325.

Russell, R. S., \& Taylor, B. W. (2008). Operations management along the supply chain. John Wiley \& Sons: New York.

Siagian, Y. M. (2007). Aplikasi Supply Chain Management. 2007: Grasindo.

Simatupang, R. S. (2017). Penerapan Metode Period Order Quantity (POQ) dalam Pengendalian Persediaan Palm Kernel Oil (PKO) dan Crude Palm Oil (CPO).(Studi Kasus: PT Perkebunan Nusantara III Medan).

Taryana, N. (2008). Analisis Pengendalian Persediaan Bahan Baku PAda Produk Sepatu Dengan Pendekatan Teknik Lot Sizing Dalam Mendukung Sistem MRP (Studi Kasus di PT. Sepatu Mas Idaman, Bogor). . Bogor: Fakultas Teknologi Pertanian, Institut Pertanian Bogor.

Tersine, R. J. (1994). Principles of inventory and materials management. London: Prentice Hal.

Tiwari, S., Jaggi, C. K., Gupta, M., \& Cárdenas-Barrón, L. E. (2018). Optimal pricing and lotsizing policy for supply chain system with deteriorating items under limited storage capacity. International Journal of Production Economics, 200, 278-290.

Wonglimpiyarat, J. (2018). The pursuit of original equipment manufacturer strategy: insights from an Asian country. $R \& D$ Management, 48(2), 243-252. 